\title{
OBITUARIES
}

Obituaries should be submitted by email to Laura Pacey at I.pacey@nature.com.

All submitted obituaries should be 450 words maximum in length (apart from obituaries for past presidents of the BDA where the length should be 800 words).

Content of the obituary is down to the individual author, and the approval of the family should

be given for the obituary prior to submission to the $B D J$.

\section{ANDY HOLDEN}

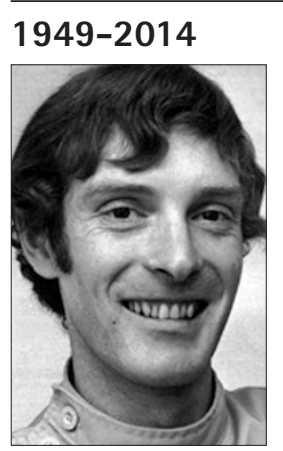

His athletics accolades included winning the 1969 English junior crosscountry championships, and competing at the Munich Olympics in 1972 - the year he set the UK 3,000 $\mathrm{m}$ steeplechase record (8 $\min 26.4 \mathrm{sec}$ ).

He won world cross-country gold for England in 1979, and a string of marathons - including Bermuda three times.

After striding clear of the field in the 1986 Belfast Marathon, he was led astray by the lead car - twice. He still managed to finish second, and joked afterwards: 'It's just one of those things which happen - it was an Irish marathon.'

Holden was a dedicated coach to hundreds of youngsters at Tipton Harriers and liked nothing better than to turn out for the club, however small the meeting. He once resuscitated a fellow runner who had collapsed after a training run. Among peers, he was known for his good deeds.

On one run, he came across a dog that was weighed down with bricks in a canal. He adopted it, and Schnicky became his faithful running companion for many years.

Andy Holden, who three years ago suffered an aortic aneurysm, is survived by his wife, Paula, and by their three sons and one daughter.

This obituary is based on excerpts taken from Andy Holden's obituary published in the Telegraph, 14 Jan 2014.

Chris Musson

\section{DAVID ENGLISH}

\section{9-2014}

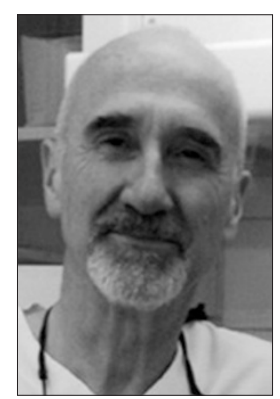

David English, whose thirst for knowledge and unique style set him apart from his colleagues, died in a skiing accident on 11 February 2014 in Vercorin, Switzerland.

David was born on 12 January 1949 and raised in Harrogate. David qualified in dentistry from the London Hospital the Norwich dentist in 1977, having previously achieved a BSc in Human Biology, and an MSc in Biomechanics from the University of Surrey. While working as an associate in Great Yarmouth, in his spare time he singlehandedly converted premises in Norwich into the St Augustine's dental practice, which he ran with his wife Heather, as practice manager, until his tragic death.

A colleague of great enthusiasms, David brought much to his practice of dentistry. His grounding in general science, together with an unfailingly curious mind led him to constantly question the perceived wisdom in dentistry. As a founding member of the Norwich Dentists Study Group in 1986 he could always be relied upon to ask the challenging question.

In 2006 he attended the conference of the Academy of Enhanced Microscope Dentistry in Tucson Arizona. This proved to be his dental Damascene moment. He became fascinated by the possibilities that microscopy opened up for clinical dental practice with the opportunity, as he put it, 'of actually seeing what we are doing'. As a member of the European Society of Microscope Dentistry, he became its British 'ambassador', giving presentations to the Society, and also to the Winter Dental Technology Conference in Vail Colorado, on clinical dental microscopy in general practice.

David was loving husband to Heather, and father to Matthew, Catherine and Oliver. He was a bass guitarist of talent, playing in Norfolk bands, the Exit Blues Band and the Lubes. He built his own house. An enthusiastic skier, he tragically died indulging in the sport that he loved. His courteous manner, sense of humour, and empathy for his fellow man, will be fondly remembered by family, friends, colleagues and patients alike.

Stuart Tucker With his dental nurse, he went to the pub, stood the landlord under a dartboard spotlight, gave him a mouthful of whisky and yanked the tooth out. 